\title{
Pathologic Stage II Gastric Cancer AJCC v8
}

National Cancer Institute

\section{Source}

National Cancer Institute. Pathologic Stage // Gastric Cancer A/CC v8. NCI Thesaurus. Code C133659.

Stage II includes: IIA: (T1, N2, M0); (T2, N1, M0); (T3, N0, M0); IIB: (T1, N3a, M0); (T2, N2, M0); (T3, N1, M0); (T4a, N0, M0). T1: Tumor invades the lamina propria, muscularis mucosae, or submucosa. T2: Tumor invades the muscularis propria. T3: Tumor penetrates the subserosal connective tissue without invasion of the visceral peritoneum or adjacent structures. T4a: Tumor invades the serosa (visceral peritoneum). N0: No regional lymph node metastasis. N1: Tumor with metastasis in one or two regional lymph nodes. N2: T umor with metastasis in three to six regional lymph nodes. N3a: Tumor with metastasis in seven to fifteen regional lymph nodes. M0: No distant metastasis. (AJCC 8th ed.) 